\title{
Economic Evaluation of Rice-Maize-Green Manure Cropping System under Different Tillage and Weed Management Practices in Conservation Agriculture
}

\author{
P. Leela Rani* and M. Yakadri \\ AICRP on Weed Management, College of Agriculture, Rendranagar, Professor Jayashankar \\ Telangana State Agricultural University, Hyderabad-500030, India \\ *Corresponding author
}

\author{
A B S T R A C T
}

\begin{tabular}{|l|}
\hline Ke y w or d s \\
CT (conventional \\
tillage), ZT (zero \\
tillage), System \\
productivity, Rice- \\
maize-green \\
manure.
\end{tabular}

A field investigation was carried out at college farm, Professor Jayashankar Telangana State Agricultural University, Rajendranagar, Hyderabad during 2014-15 and 2015-16 with five tillage treatments CT (transplanted), CT (transplanted), CT (direct-seeded), ZT (direct-seeded) and ZT+R (direct-seeded) for kharif rice fb $\mathrm{CT}, \mathrm{ZT}, \mathrm{CT}, \mathrm{ZT}+\mathrm{R}$ and $\mathrm{ZT}+\mathrm{R}$ treatments for rabi maize in sequence as main treatments and 3 weed management practices (chemical method, IWM and weedy check) as subplots in split plot design replicated thrice. Mean data of system productivity (rice-maize-green manure (dhaincha) system) and economic analysis showed that, more system productivity, net returns and B C ratio was obtained under conventional tillage (CT) kharif transplanted rice followed by rabi maize under conventional tillage (12777 $\mathrm{kg} \mathrm{ha}^{-1}$, Rs 1, 09,003 ha ${ }^{-1}$ and 2.53) and zero

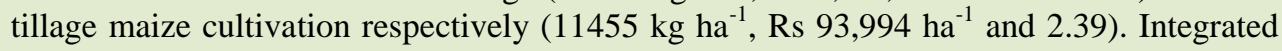
weed management practices recorded more system productivity, net returns and $\mathrm{BC}$ ratio (12126 kg ha ${ }^{-1}$, Rs 1, 02, $625 \mathrm{ha}^{-1}$ and 2.51) for kharif aerobic/transplanted rice (bispyribac sodium $25 \mathrm{~g} / \mathrm{ha}$ as early PoE at $15 \mathrm{DAT}$ fb HW at $40 \mathrm{DAT}$ ) followed by rabi maize (atrazine $1000 \mathrm{~g} \mathrm{ha}^{-1}+$ paraquat $600 \mathrm{~g} \mathrm{ha}^{-1}$ as PE fb $\mathrm{HW}$ at $40 \mathrm{DAS}$ ) in sequence respectively.

\section{Introduction}

Post green revolution era has many challenges like stagnated net sown area, reduction in per capita land availability, climate change effects and deterioration of land quality. Conservation agriculture (CA) has emerged as an effective strategy to enhance sustainable agriculture worldwide. Rice-relay pulse crop is an important crop sequence covering 0.3 million ha area in Andhra Pradesh. For the past half decade, the greengram and blackgram were subjected to yellow vein mosaic and Cuscuta problem. In addition to this, since 2003 onwards in Krishna delta of Andhra Pradesh, due to late release of water, transplanting of rice is delayed and ultimately timely sowing of blackgram as relay crop is not possible. Then, farmers are switching over to non-traditional crop like maize in rice fallows as an alternative to blackgram. Under the emerging and potential crop sequence (rice-maize) in coastal region of Andhra Pradesh and Telangana state, conventional tillage maize after kharif rice under heavy textured soil needs $25-30 \%$ more energy for 
field preparation, which limits the farm profitability and delays maize sowing leading to lower productivity. Conservation agriculture (CA)-based technologies such as zero, reduced tillage facilitates timely sowing, increased yield, lower production costs and boost income. Further no till maize in rice fallow demonstrated a potential benefit of saving on cost of production ranging from Rs.3800-5500/ha. Weeds are the one of the biggest constraints of the adoption of conservation agriculture. Reduction in tillage intensity or frequency has an influence on weed management. Implementation of conservation agriculture has often caused yield reduction because reduced tillage failed to control weed interference. Crop yields can be similar for both conventional as well as in conservation tillage systems if weeds are controlled and crop stands are uniform (Mahajan et al., 2002). From Chhattisgarh Pal et al., (2015) reported conventional tillage practices performed better as compared to minimum tillage practices in terms of yields of various rabi crops. In view of this, the present experiment was conducted with an object to identify the economically viable tillage and weed management for resource conservation technologies.

\section{Materials and Methods}

The experiment was conducted at college farm, Professor Jayashankar Telangana State Agricultural university, Rajendranagar (PJTSAU), Hyderabad during 2014-15 and 2015-16 situated at an altitude of $542.3 \mathrm{~m}$ above mean sea level at $17^{\circ} 19^{\prime} \mathrm{N}$ latitude and $78^{\circ} 23^{\prime}$ E longitude. The experiment was laid out in split plot design with 5 tillage treatments $\mathrm{T}_{1}: \mathrm{CT}$ (transplanted), $\mathrm{T}_{2}: \mathrm{CT}$ (transplanted+green manure), $\mathrm{T}_{3}: \mathrm{CT}$ (directseeded), $\mathrm{T}_{4}: \mathrm{ZT}$ (direct-seeded), $\mathrm{T}_{5}: \mathrm{ZT}+\mathrm{R}$ (direct -seeded) for kharif rice under transplanted and aerobic system fb $\mathrm{T}_{1}: \mathrm{CT}$, $\mathrm{T}_{2}: \mathrm{ZT}, \mathrm{T}_{3}: \mathrm{CT} . \mathrm{T}_{4}: \mathrm{ZT}+\mathrm{R}, \mathrm{T}_{5}: \mathrm{ZT}+\mathrm{R}$ for $r a b i$ maize in sequence as main plots and 3 weed management treatments $\mathrm{W}_{1}$ :chemical (pendimethalin as PE $1000 \mathrm{~g} \mathrm{ha}^{-1}$ (aerobic rice) /bensulfuron+pretilachlor $660 \mathrm{~g} \mathrm{ha}^{-1}$ (transplanted rice) as $\mathrm{PE}$ at 3-5 DAT $f b$ bispyribac sodium $25 \mathrm{~g} \mathrm{ha}^{-1}$ as $\mathrm{PoE}$ at $20-25$ DAS (2-3 weed leaf stage), $\mathrm{W}_{2}$ :integrated weed management (bispyribac sodium $25 \mathrm{~g}$ $\mathrm{ha}^{-1}$ as early PoE at 15 DAS/DAT (2-3 weed leaf stge) fb HW at 40 DAS/DAT (aerobic and and transplanted rice) and $\mathrm{W}_{3}$ : weedy check for kharif rice and $\mathrm{W}_{1}$ : chemical (atrazine $1000 \mathrm{~g} \mathrm{ha}^{-1}+$ paraquat $600 \mathrm{~g} \mathrm{ha}^{-1} \mathrm{PE}$ fb 2-4 D $1000 \mathrm{~g} \mathrm{ha}^{-1}$ at 20-25 DAS as PoE, $\mathrm{W}_{2}$ :integrated weed management (atrazine $1000 \mathrm{~g} \mathrm{ha}^{-1}$-paraquat $600 \mathrm{~g} \mathrm{ha}^{-1} \mathrm{PE}$ fb HW at 40 DAS) and $\mathrm{W}_{3}$ : weedy check for rabi maize crop in sequence as subplots and replicated thrice with MTU-1010 and cargil 900M as test varieties for rice and maize respectively. During summer season greenmanure crop dhaincha was raised in all the treatments except in $T_{1}$ treatment in sequence for both rice and maize crops. The herbicide treatments were imposed as per the technical programme of the work, however paraquat did not apply to the conventional tillage maize treatments and the remaining package of practices were followed as per the recommendations of PJTSAU.

Rice equivalent yield (REY) was calculated to compare system performance by converting the yield of maize crop into equivalent rice yield on a price basis, using the formula:

RYE of maize $-\mathrm{Y}_{\mathrm{x}}\left(\mathrm{P}_{\mathrm{X}} / \mathrm{P}_{\mathrm{r}}\right)$

Where $Y_{X}$ is the yield of crop maize $\left(\mathrm{kg} \mathrm{ha}^{-1}\right)$, $P_{x}$ the price of crop maize and $P_{r}$ is the price of rice. Net return or profit was calculated by subtracting cost of cultivation from the gross returns, including by-product value to gross return. Prices used for harvest products were minimum support price during the experimental period. The benefit: cost ratio 
(BCR) was calculated by dividing the gross return by the production cost for individual crops and for the system.

\section{Results and Discussion}

\section{Kharif rice}

Summary of kharif rice results in rice maize green manure sequence of two years revealed that, tillage and weed management treatments exerted significant influence on kharif rice yields (Table 1). Conventional tillage transplanted rice $\left(T_{2}\right.$ and $\left.T_{1}\right)$ with summer green manure recorded slightly more yield over without green manure treatment for two years and were comparable with each other. The grain yield obtained from conventional tillage aerobic $\left(\mathrm{T}_{3}\right)$ and zero tillage aerobic $\left(\mathrm{T}_{4}\right.$ and $\mathrm{T}_{5}$ ) is significantly less compared to CT transplanted rice $\left(\mathrm{T}_{1}\right.$ and $\left.\mathrm{T}_{2}\right)$. Tillage treatment also showed similar trend on straw yield and $\mathrm{HI}$ as that of grain yield. Alam et al., (2014) and Pal et al., (2015) also reported the yield increase in conventional tillage over conservation tillage practices.

Among the different weed management practices either IWM practice (bispyribac sodium $25 \mathrm{~g} \mathrm{ha}^{-1}$ as early PoE at 15 DAS/DAT (2-3 weed leaf stage) fb HW at 40 DAS/DAT) or sequential application of herbicides (pendimethalin as PE $1000 \mathrm{~g} \mathrm{ha}^{-1}$ (aerobic rice)/ bensulfuron+pretilachlor $666 \mathrm{~g}$ $\mathrm{ha}^{-1}$ (transplanted rice) proved to be equally effective to control weeds (data is not given) and to obtain significantly more yields over weedy check treatment. Straw yield and harvest index also showed the similar trend as that of grain yield. Yield reduction of $38.38 \%$ and $38.36 \%$ was noticed in weedy check treatment as minimum grain and straw yields was recorded under weedy check treatment due to more weed infestation resulted in poor crop growth and lower yield. These results are in accordance with findings of Gaurav et al.,
(2015), who reported pre-emergence application of pendimethalin $\mathrm{fb}$ bispyribac sodium significantly reduced the density of grasses, sedges and broad leaf weeds and there by increased the grain yield. However rice grain yield was not affected due to interaction effect of tillage and weed management practices..

\section{Rabi maize}

Tillage and weed management practices exerted profound influence on rabi maize grain yield grown in sequence after kharif rice (Table 2). Maize crop raised under conventional tillage (CT) with preceded kharif conventional aerobic rice $\left(\mathrm{T}_{3}\right)$ and transplanted rice $\left(T_{1}\right)$ treatments showed better performance with increased and comparable grain yield during 2014-15 (9072 $\mathrm{kg}$ and $8717 \mathrm{~kg} \mathrm{ha}^{-1}$ ) and 2015-16 (6572 kg and $6168 \mathrm{~kg} \mathrm{ha}^{-1}$ ) respectively. Grain yield from these treatments is significantly superior over grain yield recorded from maize crop grown under zero till condition. However the grain yield obtained from zero till treatments was comparable with each other. But any of the tillage treatments did not influence the stover yield, but HI followed the same trend as that of grain yield. Experimental results of Mukundam et al., (2011) under clay loam soil showed the maximum plant height and yield of maize with conventional tillage than that under zero tillage.

Among the weed management practices pre emergence application atrazine $1000 \mathrm{~g} \mathrm{ha}$ ${ }^{1}$ paraquat $600 \mathrm{~g} \mathrm{ha}^{-1} \mathrm{fb} \mathrm{HW}$ at $40 \mathrm{DAS}$ recorded significantly more grain yield and was comparable with sequential application of atrazine $1000 \mathrm{~g} \mathrm{ha}^{-1}+$ paraquat $600 \mathrm{~g} \mathrm{ha}^{-1}$ as PE fb 2-4D sodium salt $1000 \mathrm{~g} \mathrm{ha}^{* 1}$ at 20-25 DAS as post emergence application during two years of study. Yield reduction of $58.47 \%$ and $58.22 \%$ was noticed with weedy chek treatment during the study respectively due to 
season-long crop-weed competition. Stover yield was also affected by weed management treatments as that of grain yield with improved harvest index in similar treatments.

Table.1 Effect of tillage and weed management practices on grain yield, straw yield and harvest index of kharif rice in rice-maize-green manure cropping system (2014 and 2015)

\begin{tabular}{|c|c|c|c|c|c|c|c|}
\hline & Treatments & $\begin{array}{c}\text { Grain } \\
\text { yield } \\
\left(\mathrm{Kg} \mathrm{ha}^{-1}\right)\end{array}$ & $\begin{array}{c}\text { Grain } \\
\text { yield } \\
\left(\mathrm{Kg} \mathrm{ha}^{-1}\right)\end{array}$ & $\begin{array}{c}\text { Straw } \\
\text { yield } \\
\left(\mathrm{Kg} \mathrm{ha}^{-1}\right)\end{array}$ & $\begin{array}{c}\text { Straw } \\
\text { yield } \\
\left(\mathrm{Kg} \mathrm{ha}^{-1}\right)\end{array}$ & $\mathrm{HI}$ & $\mathrm{HI}$ \\
\hline & & 2014 & 2015 & 2014 & 2015 & 2014 & 2015 \\
\hline \multicolumn{8}{|l|}{ Main Plots } \\
\hline $\mathrm{T}_{1}$ & CT (Transplanted) & 3708 & 4996 & 5342 & 6,573 & 40.32 & 43.08 \\
\hline $\mathrm{T}_{2}$ & CT (Transplanted) & 3783 & 5136 & 5301 & 6,266 & 42.71 & 44.49 \\
\hline $\mathrm{T}_{3}$ & CT (Direct-seeded) & 874 & 1196 & 1868 & 2,351 & 31.69 & 31.91 \\
\hline $\mathrm{T}_{4}$ & ZT (Direct-seeded) & 562 & 1076 & 1237 & 2,006 & 31.77 & 29.29 \\
\hline $\mathrm{T}_{5}$ & ZT(Direct-seeded)+R & 593 & 895 & 1334 & 1,738 & 30.67 & 31.23 \\
\hline SEm+- & & & 148 & & 291 & & \\
\hline C.D $(0.05)$ & & 989 & 490 & 832 & 963 & & \\
\hline \multicolumn{8}{|l|}{ Sub Plots } \\
\hline $\mathrm{W}_{1}$ & Chemical & 2468 & 3005 & 4121 & 3992 & 35 & 40.37 \\
\hline $\mathrm{W}_{2}$ & IWM & 2229 & 3078 & 3540 & 4086 & 36 & 39.7 \\
\hline \multirow[t]{2}{*}{$\mathrm{W}_{3}$} & Un weeded & 1015 & 1897 & 1773 & 3282 & 33 & 27.93 \\
\hline & & 210 & 190 & 131 & 226 & & \\
\hline C.D $(0.05)$ & & 622 & 564 & 389 & 671 & & \\
\hline Interaction & & NS & & NS & & & \\
\hline
\end{tabular}

CT: Conventional tillage, Direct-seeded: Aerobic rice, ZT: Zero tillage, ZT+R: Zero tillage+rsidue

Table.2 Effect of tillage and weed management practices on grain yield, sover yield and harvest index of rabi maize in rice-maize-green manure cropping system (2014 and 2015)

\begin{tabular}{|c|c|c|c|c|c|c|c|}
\hline & Treatments & $\begin{array}{c}\text { Grain } \\
\text { yield } \\
\left(\mathrm{Kg} \mathrm{ha}^{-1}\right)\end{array}$ & $\begin{array}{c}\text { Grain } \\
\text { yield } \\
\left(\mathrm{Kg} \mathrm{ha}^{-1}\right) \\
\end{array}$ & $\begin{array}{c}\text { Stover } \\
\text { yield } \\
\left(\mathrm{Kg} \mathrm{ha}^{-1}\right) \\
\end{array}$ & $\begin{array}{c}\text { Stover } \\
\text { yield } \\
\left(\mathrm{Kg} \mathrm{ha}^{-1}\right) \\
\end{array}$ & HI & HI \\
\hline & & 2014 & 2015 & 2014 & 2015 & 2014 & 2015 \\
\hline \multicolumn{8}{|l|}{ Main Plots } \\
\hline$T_{1}$ & $\mathrm{CT}$ & 8717 & 6168 & 8521 & 6691 & 49.96 & 46.44 \\
\hline$T_{2}$ & $\mathrm{ZT}$ & 7505 & 4370 & 8267 & 6324 & 46.33 & 40.89 \\
\hline $\mathbf{T}_{3}$ & $\mathrm{CT}$ & 9072 & 6572 & 9063 & 6407 & 49.67 & 50.67 \\
\hline $\mathbf{T}_{4}$ & $\mathrm{ZT}+\mathrm{R}$ & 7295 & 3764 & 8003 & 6255 & 46.08 & 36.78 \\
\hline $\mathbf{T}_{5}$ & $\mathrm{ZT}+\mathrm{R}$ & 7537 & 4933 & 8047 & 7213 & 47.00 & 39.11 \\
\hline Sem & & 336 & 369 & 486 & 538 & & \\
\hline C.D(0.05) & & 1065 & 1222 & NS & NS & & \\
\hline \multicolumn{8}{|l|}{ Sub Plots } \\
\hline $\mathrm{W}_{1}$ & Chemical & 9065 & 6087 & 9128 & 6818 & 49.59 & 46.733 \\
\hline $\mathbf{W}_{2}$ & IWM & 10605 & 6629 & 10172 & 8351 & 50.00 & 44.067 \\
\hline \multirow[t]{2}{*}{$\mathbf{W}_{3}$} & Unweeded & 4405 & 2769 & 5840 & 4565 & 42.00 & 37.533 \\
\hline & & 307 & 302 & 308 & 392 & & \\
\hline C.D(0.05) & & 905 & 897 & 915 & 1165 & & \\
\hline Interaction & & NS & NS & & & & \\
\hline
\end{tabular}


Table.3 Mean system productivity and economics of rice-maize-green manure cropping system (2014 and 2015)

\begin{tabular}{|c|c|c|c|c|c|c|c|}
\hline & Kharif rice & Rabi maize & $\begin{array}{c}\text { System yield } \\
\left(\mathrm{Kg} \mathrm{ha}^{-1}\right)\end{array}$ & $\begin{array}{l}\begin{array}{l}\text { Total CC } \\
\left(\text { Rs ha }^{-1}\right)\end{array} \\
\end{array}$ & $\begin{array}{c}\text { GR (Rs } \\
\left.\text { ha }^{-1}\right)\end{array}$ & $\begin{array}{c}\text { NR } \\
\left(\text { Rs ha }^{-1}\right)\end{array}$ & $\begin{array}{l}\text { B:C } \\
\text { ratio }\end{array}$ \\
\hline \multicolumn{8}{|c|}{ Main plots } \\
\hline $\mathbf{T}_{1}$ & CT (Transplanted) & CT & 12777 & 70475 & 179478 & 109003 & 2.53 \\
\hline $\mathbf{T}_{2}$ & CT (Transplanted) & $\mathrm{ZT}$ & 11455 & 66900 & 160895 & 93994.5 & 2.385 \\
\hline $\mathbf{T}_{3}$ & CT (Direct-seeded) & CT & 9419 & 64092 & 132277 & 68185 & 2.05 \\
\hline $\mathbf{T}_{4}$ & ZT (Direct-seeded) & $\mathrm{ZT}+\mathrm{R}$ & 6936 & 60517 & 97373 & 36856 & 1.595 \\
\hline $\mathbf{T}_{5}$ & ZT(Direct-seeded) + R & $\mathrm{ZT}+\mathrm{R}$ & 7567 & 60517 & 106258 & 45741.5 & 1.74 \\
\hline \multicolumn{8}{|c|}{ Sub plots } \\
\hline $\mathrm{W}_{1}$ & Chemical & Chemical & 11123 & 65505 & 156210.5 & 90705.5 & 2.38 \\
\hline $\mathbf{W}_{2}$ & IWM & IWM & 12126 & 67670 & 170295 & 102625 & 2.51 \\
\hline $\mathbf{W}_{3}$ & Unweeded & Unweeded & 5643 & 60325 & 79272 & 18947 & 1.31 \\
\hline
\end{tabular}

In similar way Yield reduction of as high as 93\% was observed due to uncontrolled weed growth during entire crop growth season from sandy clay loam soils (Pasha et al., 2012).

\section{System productivity}

System productivity of rice-maize-green manure cropping system of two years was summerised (Table 3). Mean data of system productivity and economic analysis under different tillage practices showed that, more system productivity, gross returns, net returns and $\mathrm{B} C$ ratio was obtained in kharif rice under conventional tillage (CT) followed by rabi maize under conventional tillage (12777 $\mathrm{kg} \mathrm{ha}^{-1}$, Rs179478 ha ${ }^{-1}$, Rs $109003 \mathrm{ha}^{-1}$ and 2.53) and zero tillage maize cultivation practices respectively $(11455 \mathrm{~kg}$ ha 1 , Rs 1 , 60, $895 \mathrm{ha}^{-1}$, Rs 93, $994 \mathrm{ha}^{-1}$ and 2.39). Even though more rabi maize grain yield was recorded in rabi conventional tillage with preceded kharif rice grown on CT aerobic $\left(\mathrm{T}_{3}\right)$ and CT transplanted $\left(\mathrm{T}_{1}\right)$ system, but the increased productivity in kharif rice (transplanted) fb rabi zero till maize was due decreased rice yields when crop grown under conventional aerobic system $\left(\mathrm{T}_{3}\right)$. This resulted in reduced productivity of CT direct seeded $\left(\mathrm{T}_{3}\right)$ fb $\mathrm{CT}$ maize. Total cost of cultivation under conventional tillage is $14.1 \%$ more than conservation tillage. But the increased system productivity was due to more grain yield obtained during both the season.

Regarding weed management practices more system productivity, gross returns, net returns and $\mathrm{BC}$ ratio was obtained with integrated weed management practice $\left(12126 \mathrm{~kg} \mathrm{ha}^{-1} \mathrm{Rs}\right.$ $1,70,295 \mathrm{ha}^{-1}$, Rs 1, 02, $625 \mathrm{ha}^{-1}$ and 2.51) for kharif aerobic and transplanted rice (bispyribac sodium $25 \mathrm{~g} \mathrm{ha}^{-1}$ as early PoE at 15 DAT/2-3 weed leaf stage fb $\mathrm{HW}$ at 40 DAT) $\mathrm{fb}$ rabi maize (atrazine $1000 \mathrm{~g}$ ha ${ }^{1}$ +paraquat $600 \mathrm{~g} \mathrm{ha}^{-1}$ as $\mathrm{PE} \mathrm{fb} \mathrm{HW}$ at 40 DAS). This was followed by practicing of chemical methods in sequence for kharif rice and rabi maize (11123 $\mathrm{kg} \mathrm{ha}^{-1} \mathrm{Rs} \mathrm{1,} \mathrm{56,} 210$ $\mathrm{ha}^{-1}$, Rs 90,705 $\mathrm{ha}^{-1}$ and 2.38). Incurring of $10.85 \%$ and $7.9 \%$ money towards weed control either through integrated weed management practices or sequential application of herbicides increased the system productivity by 53.46 and $49.26 \%$ respectively. 
References

Alam, Md. K., Md. M. Islam, N. salahin and Alam, H.A. 2014. Effect of Tillage Practices on Soil Properties and Crop Productivity in Wheat-Mungbean Rice Cropping System under Subtropical Climatic Conditions. The Scientific World J., Article ID 437283:1-15

Gaurav, M.K. Singh, S.K.Verma, V.K. Verma and Tyagi, V. 2015. Integration of cultural and chemical methods for weed management in zero-till direct seeded rice. The Eco Scan, 9(1\&2): 381-384.

Mahajan, G., L.S. Brar and Walia, U.S. 2002. Phalaris minor response in wheat in relation to planting dates, tillage and herbicides. Indian J. Weed Sci., 34: 213-
215.

Mukundam, B., S. Srividya and Raja, V. 2011. Productivity and economics of rice-zero till maize as influenced by weed management practices in Southern Telangana region of Andhra Pradesh. Indian J. Weed Sci., 43(3\&4): 163-168.

Pal, A., G.P. Pali, S.Chitale, A.K. Singh and. Sahu, P.L 2015. To study the effect of tillage, mulch and fertility Levels on system productivity of different rice based Cropping system in chhattisgarh plains. The Eco scan, Special issue. VII: 331-334.

Pasha, M.d. L., D. Bhadru, L. Krishna and Naik, R.B.M. 2012. Evaluation of different herbicides in zero tillage. Madras Agri. J., 99(7-9): 471-472.

\section{How to cite this article:}

Leela Rani, P. and Yakadri, M. 2017. Economic Evaluation of Rice-Maize-Green Manure Cropping System under Different Tillage and Weed Managemnt Practices in Conservation Agriculture. Int.J.Curr.Microbiol.App.Sci. 6(3): 2363-2368. doi: http://doi.org/10.20546/ijcmas.2017.603.270 